\title{
In Healthy Primates, Circulating Autoreactive T Cells Mediate Autoimmune Disease
}

\author{
Claude P. Genain, * David Lee-Parritz, "My-Hoa Nguyen," Luca Massacesi, * Narendra Joshi, * Robert Ferrante," \\ Kathleen Hoffman, ${ }^{*}$ Michael Moseley, * Norman L. Letvin, ${ }^{5}$ and Stephen L. Hauser* \\ *University of California, San Francisco, California 94143; ${ }^{\ddagger}$ Geriatric Research Education Clinical Center, Bedford Veterans Affairs \\ Medical Center, Bedford, Massachusetts 01730; Departments of Neurology and Pathology, Boston University School of Medicine, \\ Boston, Massachusetts 01730; and ${ }^{8}$ The New England Regional Primate Research Center, Southborough, Massachusetts 01772
}

\begin{abstract}
A $T$ cell response against myelin basic protein (MBP) is thought to contribute to the central nervous system (CNS) inflammation that occurs in the human demyelinating disease multiple sclerosis. To test whether MBP-reactive T cells that are normally retrieved from the circulation are capable of inducing CNS disease, MBP-reactive $T$ cell clones were isolated from the peripheral blood of healthy, unimmunized Callithrix jacchus (C. jacchus) marmosets. This primate species is characterized by a natural chimerism of bone marrow elements between siblings that should make possible adoptive transfer of MBP-reactive T cells. We report that MBPreactive $T$ cell clones efficiently and reproducibly transfer CNS inflammatory disease between members of $C$. jacchus chimeric sets. The demyelination that is characteristic of experimental allergic encephalomyelitis induced in $C$. jacchus by immunization against human white matter did not occur after adoptive transfer of the MBP-reactive clones. It was noteworthy that encephalitogenic $T$ cell clones were diverse in terms of their recognition of different epitopes of MBP, distinguishing the response in $C$. jacchus from that in some inbred rodents in which restricted recognition of MBP occurs. These findings are the first direct evidence that natural populations of circulating $T$ cells directed against a CNS antigen can mediate an inflammatory autoimmune disease. (J. Clin. Invest. 1994. 94:1339-1345.) Key words: experimental allergic encephalomyelitis - multiple sclerosis - autoimmunity
\end{abstract}

\section{Introduction}

Myelin basic protein (MBP) ${ }^{1}$ is, in most mammalian species, the major antigen responsible for experimental allergic encepha-

Address correspondence to Claude P. Genain, MD, Department of Neurology, Box 0114, University of California, San Francisco, CA 94143.

Received for publication 16 February 1994 and in revised form 6 April 1994.

1. Abbreviations used in this paper: APC, antigen-presenting cells; CNS, central nervous system; CSF, cerebrospinal fluid; EAE, experimental allergic encephalomyelitis; MBP, myelin basic protein; MRI, magnetic resonance imaging; MS, multiple sclerosis; SI, stimulation index.

J. Clin. Invest.

(C) The American Society for Clinical Investigation, Inc. 0021-9738/94/09/1339/07 \$2.00

Volume 94, September 1994, 1339-1345 lomyelitis (EAE), an autoimmune disease which serves as a model for the human demyelinating disease multiple sclerosis (MS). In several rodent models, EAE is mediated by a $\mathrm{T}$ cell response to $\mathrm{MBP}$, as demonstrated by the ability of MBP-reactive $\mathrm{T}$ cells derived from spleen and lymph nodes of an immunized donor to adoptively transfer disease into naive syngeneic recipients (1-4). In humans, MBP-reactive $\mathrm{T}$ cells are thought to play a role in acute disseminated encephalomyelitis that follows infection or vaccination $(5,6)$ and have long been suspected as effector cells in MS (7). MBP-reactive T cells are present in the circulation of patients with MS but are also present in healthy individuals $(8-12)$. The role of these circulating $\mathrm{T}$ cell populations in the induction of human MS is unknown. Cross-species adoptive transfer experiments have been attempted with human donor cells transferred into rodent hosts, but have been unsuccessful (N. Joshi, unpublished observations) or have yielded uncertain results (13-15).

The common marmoset Callithrix jacchus ( $C$. jacchus) represents a unique species for the study of $\mathrm{T}$ cell-mediated diseases in primates, because these monkeys are born as naturally occurring bone marrow chimeras. While the individual animals arise from separate ova that are fertilized independently, the placentas of the developing animals fuse, resulting in a crosscirculation of bone marrow-derived elements between the fetuses. Thus, while the animals are genetically distinct, they share, and are tolerant to, each other's bone marrow-derived cell populations (16). The natural chimerism in $C$. jacchus theoretically makes possible adoptive transfer of functional $T$ cell populations between members of an outbred species without initiating an alloresponse. We have recently found that a relapsing-remitting form of EAE which bears a strong clinical and pathological resemblance to human MS can be induced in $C$. jacchus by immunization with human CNS white matter. ${ }^{2}$ Immunized animals display specific proliferative responses to MBP, suggesting that MBP is an autoantigen in $C$. jacchus EAE. Thus, this outbred species of non-human primate is characterized by bone marrow chimerism and susceptibility to CNS disease, creating an opportunity to elucidate the antigenic repertoire and the encephalitogenic potential of circulating populations of MBP-reactive $\mathrm{T}$ cells.

Here we show that MBP-reactive $\mathrm{T}$ cell clones can be derived from the circulation of unimmunized, healthy $C$. jacchus. Furthermore, these $\mathrm{T}$ cell clones are consistently able to induce an inflammatory CNS disease by adoptive transfer. Different $T$

2. Massacesi, L., C. P. Genain, D. Lee-Parritz, N. L. Letvin, and S. L. Hauser, manuscript submitted for publication. 
cell clones derived from the same animal and reactive against different epitopes of MBP appear to be equally encephalitogenic. The data are the first direct demonstration that $T$ cells reactive against a self-antigen and present in the normal circulating pool are capable of mediating an autoimmune disease.

\section{Methods}

Animals. C. jacchus marmosets were maintained in primate colonies at the University of California, San Francisco and New England Regional Primate Research Center. The animals used in this study were cared for in accordance with the guidelines of the Committee on Animals of the Harvard Medical School and those of the Committee on Care and Use of Laboratory Animals of the Institute of Laboratory Animal Resources, National Research Council. A maximum of $2.5 \mathrm{ml}$ of blood every other week was taken from each animal. CSF was obtained by puncture of the cisterna magna. Phlebotomy, cisternal puncture, and intravenous transfer of $\mathrm{T}$ cells were done under brief anesthesia (Ketamine, 10 $\mathrm{mg}$ i.m.). Magnetic resonance imaging (MRI) was performed under anesthesia with Propofol, $20-50 \mathrm{mg} / \mathrm{h}$ in intravenous drip.

Production and characterization of $T$ cell clones. MBP-reactive T cell clones were derived from PBMC of naive (e.g., unimmunized) $C$. jacchus by limiting dilution. Freshly isolated PBMC were cultured at $10^{5}$ cells/well in 96 round-bottom well plates (Corning Inc., Corning, NY) with purified human MBP ( $50 \mu \mathrm{g} / \mathrm{ml}$ final concentration) (17) in RPMI 1640 supplemented with $2 \mathrm{mM}$ glutamine (Gibco, Grand Island, NY), $20 \mathrm{mM}$ Hepes buffer and $10 \%$ controlled processed serum replacement-2 (CPSR-2) (Sigma Chemical Co., St. Louis, MO), and penicillin/ streptomycin/gentamycin at standard concentrations (Gibco). After 3 d the culture medium was supplemented with $10 \%$ heat-inactivated human AB serum (Pel-Freez Biologicals, Rogers, AR), 10\% human T cell growth factor (Cellular Prods. Inc., Buffalo, NY), $40 \mathrm{U} / \mathrm{ml}$ recombinant IL-2 (Hazelton Systems, Inc., Aberdeen, MD) and 4 U/ml IL-4 (Genzyme Corp., Cambridge, MA) and this growth medium was changed every $3 \mathrm{~d}$ for $9 \mathrm{~d}$. T cells were restimulated at the end of the cycle by addition of $10^{5}$ syngeneic and/or chimeric freshly isolated PBMC pulsed with MBP $(50 \mu \mathrm{g} / \mathrm{ml})$ and irradiated (3000 rad) as APC. $\mathrm{T}$ cell clones were expanded by multiple cycles of restimulation with MBP/APC followed by culture in growth medium. After 4-6 cycles, MBP-reactive clones were identified and characterized for peptide specificity by $\left[{ }^{3} \mathrm{H}\right]$ thymidine incorporation in a $72-\mathrm{h}$ proliferation assay. 5 $\times 10^{4} \mathrm{~T}$ cells were cultured with $10^{5}$ irradiated APC and $25 \mu \mathrm{g} / \mathrm{ml}$ of MBP, $50 \mu \mathrm{g} / \mathrm{ml}$ of each MBP-peptide or no antigen (background) in $10 \%$ CPSR- 2 medium for $72 \mathrm{~h} .18 \mathrm{~h}$ before termination, $\left[{ }^{3} \mathrm{H}\right]$ thymidine $(0.5 \mu \mathrm{Ci} /$ well $)$ was added. The stimulation index (SI) was measured for each MBP-reactive clone on the day of transfer and was calculated as the ratio of incorporation of $\left[{ }^{3} \mathrm{H}\right]$ thymidine (cpm) in the presence of MBP over that of background. Fine mapping of peptide reactivity was studied using a panel of sixteen 20-mer synthetic peptides corresponding to overlapping peptides of human MBP. Human and monkey MBP differ by only 4 of 172 amino acids (18). All peptides recognized by the MBP-reactive $\mathrm{T}$ cell clones shared sequence identity with monkey MBP, with the exception of one clone directed against the human 143162 amino acid sequence that differs by a single amino acid between the species. $T$ cell clones used in control experiments were isolated by the same limiting dilution technique but did not react with MBP or peptides in the proliferation assay.

Adoptive transfer. At the end of the stimulation cycle $10^{7} \mathrm{~T}$ cells were rested for $48 \mathrm{~h}$ in CPSR-2 medium, then restimulated with either: MBP $(50 \mu \mathrm{g} / \mathrm{ml})$ in the presence of irradiated $(3000 \mathrm{rad})$ syngeneic/ chimeric PBMC as APC; or $4 \mu \mathrm{g} / \mathrm{ml}$ concanavalin A. Control, MBP nonreactive clones were restimulated with $4 \mu \mathrm{g} / \mathrm{ml}$ concanavalin A. Growth medium was added after $48 \mathrm{~h}$, and $24 \mathrm{~h}$ later cells were harvested, washed with RPMI, resuspended in $2 \mathrm{ml}$ of $0.9 \%$ saline i.v. and injected into the popliteal vein, followed immediately by intravenous injection of $10^{10}$ killed Bordetella pertussis organisms. $48 \mathrm{~h}$ later, a second intravenous injection of Bordetella pertussis was administered. In an additional control group, two animals received the two injections of Bordetella pertussis but no cells.
Table I. Effective Cross-presentation of MBP and the Synthetic Peptide 153-172 to the T cell Clone 31.N.2.73 by APC from Chimeric Siblings

\begin{tabular}{|c|c|c|c|}
\hline \multicolumn{4}{|c|}{ cpm (SI) } \\
\hline \multirow{2}{*}{$\begin{array}{c}\begin{array}{c}\text { Animal source } \\
\text { of APC }\end{array} \\
A^{*}\end{array}$} & \multirow{2}{*}{$\begin{array}{c}\text { Background } \\
1,350\end{array}$} & $\begin{array}{c}\text { MBP } \\
(25 \mu \mathrm{g} / \mathrm{ml})\end{array}$ & $\begin{array}{c}\text { aa } 153-172 \\
(50 \mu \mathrm{g} / \mathrm{ml})\end{array}$ \\
\hline & & $15,159 \quad(8.8)$ & $14,761 \quad(9.1)$ \\
\hline & 1,887 & 13,498 & \\
\hline \multirow[t]{2}{*}{ B } & 2,107 & $13,531 \quad(6.2)$ & $13,112 \quad(5.8)$ \\
\hline & 2,427 & 14,943 & \\
\hline \multirow[t]{2}{*}{$\mathrm{C}$} & 654 & 11,835 & 15,239 \\
\hline & 679 & 10,954 & \\
\hline
\end{tabular}

Clone 31.N.2.73 was derived from animal A $\left(^{*}\right)$ in chimeric set 3 (see Table II).

Assessment of EAE. The appearance of EAE was monitored in recipient animals by daily clinical evaluation, examination of CSF, MRI, and neuropathologic criteria. The severity of disease was graded by two independent observers blinded as to the identity of the clone transferred: 0 , normal; 1 , lethargy, anorexia, weight loss; 2 , ataxia and either paraparesis/monoparesis, sensory loss or brain stem syndrome including gaze palsy, blindness or dysarthria; 3, paraplegia or hemiplegia; 4, quadriplegia. Postmortem examination was performed on formalin-fixed tissues.

\section{Results}

Adoptive transfer of EAE by natural MBP-reactive $T$ cell clones. We first demonstrated that APC from chimeric siblings were equivalent to syngeneic APC in the presentation of MBP or the relevant peptide to the $\mathrm{T}$ cell clones derived from one member of the sets (Table I). Therefore, selected clones could be adoptively transferred into the animal of origin or into a chimeric sibling. Table II summarizes the results for five adoptive transfers performed with MBP-reactive clones, and three control adoptive transfers carried out with MBP nonreactive clones (chimeric sets 1-4). In chimeric set 5, animals received intravenous Bordetella pertussis but no cells. The SI of the different MBP-reactive clones used for adoptive transfers ranged from 6 to 215 . No reactivity to MBP (SI < 1) was detected in the control clones. Clinical signs of EAE developed within 13-27 d after T cell transfer in all five $C$. jacchus that received an MBP-reactive $T$ cell clone (chimeric set 1 , animals A and B; chimeric set 2, animal A; chimeric set 3, animals A and B), and in no control animal. Signs included weight loss, sensory loss in the lower limbs, tremor, mono- or paraparesis, or a brain stem syndrome consisting of an altered cry and disordered conjugate gaze. Disease severity did not exceed grade 2 (Table II). In two animals not killed, clinical signs persisted for a period of 4-8 wk before gradually disappearing (animals $A$ and $B$, chimeric set 3 ). In one experiment (chimeric set 3, clone 31.N.2.73), concanavalin A appeared as efficient as MBP for stimulation of the encephalitogenic clone prior to transfer. In each animal with EAE, cerebrospinal fluid (CSF) pleocytosis indicative of central nervous system (CNS) inflammatory disease was present at the onset of clinical signs (Table II). Sequential CSF analyses performed in two animals (chimeric set 3 ) indicated that pleocytosis preceded the onset of neurologic signs (Fig. 1). In the same two animals, MRI studies were performed after the onset of the neurologic signs. Foci of in- 
Table II. Adoptive Transfer of EAE by Naturally Occurring MBP-reactive T Cell Clones

\begin{tabular}{|c|c|c|c|c|c|c|c|c|}
\hline $\begin{array}{l}\text { Chimeric } \\
\text { set }\end{array}$ & Animal & $\begin{array}{l}\text { No. of cells } \\
\text { transferred }\end{array}$ & $\begin{array}{l}\text { Clone No. and } \\
\text { specificity }\end{array}$ & SI & Onset & Clinical signs (EAE grade) & CSF & Pathology \\
\hline & & & & & $d$ after transfer & & $W B C / \mathrm{mm}^{3}$ & \\
\hline \multirow[t]{3}{*}{1} & A & $10^{7}$ & $\begin{array}{c}24 . \mathrm{N} .2 .14 \\
\text { aa } 153-172^{\ddagger}\end{array}$ & 52 & 13 & $\begin{array}{l}\text { Extraocular motor palsy, } \\
\text { dysarthria euthanized day } 20 \\
\text { (2) }\end{array}$ & 750 & - \\
\hline & B* & $10^{7}$ & $\begin{array}{l}24 . N .2 .7 \\
\text { aa } 11-30^{\ddagger}\end{array}$ & 215 & 14 & $\begin{array}{l}\text { Paraparesis and sensory loss } \\
\text { lower limbs: euthanized day } \\
20 \text { (2) }\end{array}$ & 60 & + \\
\hline & C & $10^{7}$ & $\begin{array}{c}\text { 24.N.2.5 } \\
\text { Nonreactive }\end{array}$ & - & (48 d observation) & None: euthanized day $48(0)$ & 9 & - \\
\hline \multirow[t]{2}{*}{2} & A & $10^{7}$ & $\begin{array}{c}21 . N .2 .26 \\
\text { aa } 143-1.62^{\ddagger}\end{array}$ & 21 & 13 & $\begin{array}{l}\text { Paraparesis, tremor; euthanized } \\
\text { day } 22 \text { (2) }\end{array}$ & 360 & + \\
\hline & B & $10^{7}$ & $\begin{array}{c}\text { 21.N.2.23 } \\
\text { Nonreactive }\end{array}$ & - & (94 d observation) & None $(0)$ & 0 & ND \\
\hline \multirow[t]{3}{*}{3} & $A^{*}$ & $10^{7}$ & $\begin{array}{c}\text { 31.N.2.73 } \\
\text { aa } 153-172^{\ddagger}\end{array}$ & 8.8 & 14 & $\begin{array}{l}\text { Complete sensory loss lower } \\
\text { limbs (2) }\end{array}$ & 75 & ND \\
\hline & B & $10^{7}$ & $\begin{array}{c}\text { 31.N.2.73 } \\
\text { aa } 153-172^{8}\end{array}$ & 6.3 & 27 & Left lower leg weakness (2) & 465 & ND \\
\hline & C & ND & & & & & & \\
\hline 4 & $A^{*}$ & $10^{7}$ & $\begin{array}{c}\text { 6.N.2.0 } \\
\text { Nonreactive }\end{array}$ & - & (270 d observation) & None $(0)$ & 0 & ND \\
\hline \multirow[t]{2}{*}{5} & A & i.v. pertussis & - & - & (72 d observation) & None $(0)$ & 0 & ND \\
\hline & B & i.v. pertussis & - & - & (48 d observation) & None $(0)$ & ND & ND \\
\hline
\end{tabular}

* Origin of MBP-reactive T cell clones and control, non-MBP reactive clones used for transfer, e.g., animal B, chimeric set 1; animal C, chimeric set 2 (not shown); animal A, chimeric set 3; animal A, chimeric set 4. Stimulation of $T$ cell clones prior to transfer was performed with either MBP $\left({ }^{\ddagger}\right)$ or concanavalin A $\left({ }^{8}\right)$. MPB-reactive T cell clones in chimeric sets 1 and 2 were stimulated with MBP. In chimeric set 3, two adoptive transfer were performed with the same clone (31.N.2.73) stimulated with either MBP (animal A) or concanavalin A (animal B). All control, non MBP-reactive clones were stimulated with concanavalin A. ND, Not done.

creased signal intensity on T2-weighted images were present, suggestive of edema (Fig. $2 A$ ). On T1-weighted images, obtained following administration of contrast material, areas of gadolinium enhancement appeared in CNS white matter, indicative of blood brain barrier breakdown (Fig. 2, $B$ and $C$ ). Some of the MRI findings in the animals studied correlated with the clinical signs. For example, animal B displayed left lower limb weakness and a lesion within the right side of the midbrain. Animal A had sensory loss in the lower limbs and evidence of a lesion with mass effect in the posterior column of the cervical cord (Table II and Fig. 2, $B$ and $C$ ). Control animals were observed for a period ranging between 48 and $270 \mathrm{~d}$. None of the five $C$. jacchus in this group developed clinical signs of
EAE. CSF studies performed at day 14 and 28 after transfer were normal (Table II).

Postmortem examination of the cerebrum and the spinal cord was performed in three animals with EAE and in one control animal. The animals with EAE were killed between day 20 and day 22 after adoptive transfer of $\mathrm{T}$ cell clones, corresponding to 6-9 $d$ after the onset of the clinical signs (Table II). At this stage of disease, occasional areas of necrosis and inflammation were present in two of the diseased animals (Table II, Fig. 2D), but foci of demyelination and gliosis were notably absent. No lesion was observed in the control animal studied.

Antigenic repertoire of natural encephalitogenic $T$ cell clones. The frequency of MBP-reactive $\mathrm{T}$ cell clones in circulat-

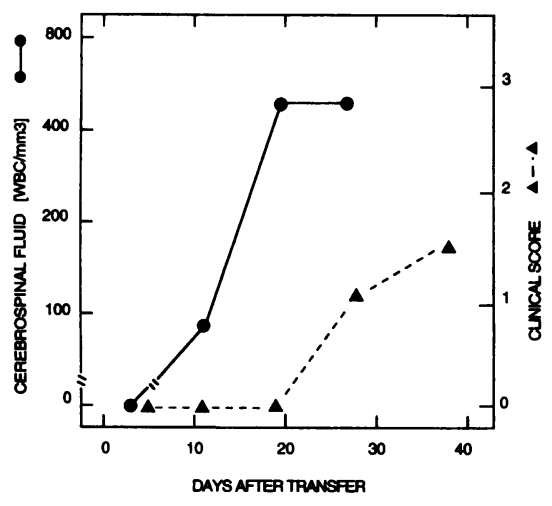

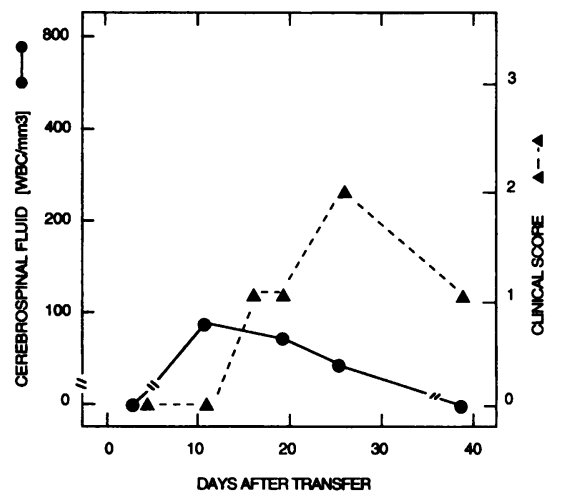

Figure 1. CSF pleocytosis precedes the onset of clinical signs in adoptive EAE. Two animals were studied by sequential cisternal puncture and clinical examination. For each, the CSF cell count (circle) and corresponding clinical score (triangle) is shown in relation to the time of adoptive transfer. 


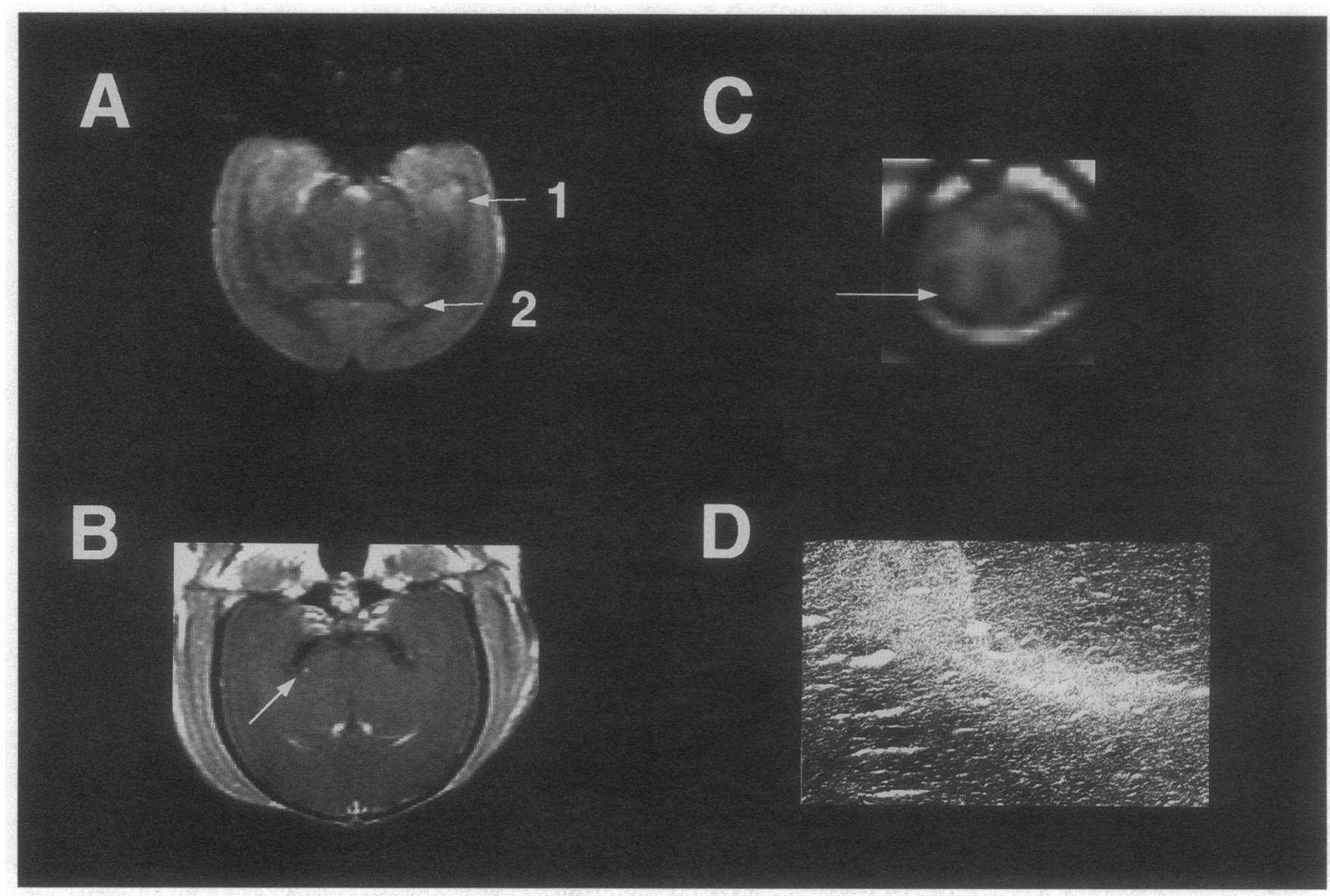

Figure 2. MRI and Pathologic Findings in adoptive EAE. (A) A focus of increased T2 signal intensity appears in the left temporal-parietal white matter (1) and mass effect from a second lesion produces thinning of the left splenium of the corpus callosum (2); (B) A T1 scan following intravenous administration of Gadolinium-DTPA demonstrates an enhancing lesion within the right side of the midbrain (arrow); chimeric set 3 , animal B. (C) Cervical cord section demonstrates a T1-Gadolinium enhancing lesion in the right posterior column (arrow) with mass effect on the posterior horn of the gray matter of the cord; chimeric set 3, animal A. (D) Pathological example of a necrotic focus without demyelination in the dorsal mesencephalon. Frozen section. (Hematoxylin/eosin, $\times 300$ ); chimeric set 2, animal A.

ing PBMC of normal $C$. jacchus ranged between 3 and 7 per $10^{-7}$, similar to the frequency estimated to be present in the circulation of healthy humans (8-12). Mapping of the antigenic peptides recognized by individual clones indicated that multiple regions of the MBP molecule were recognized by naturally occurring T cells (Fig. 3). The pattern of reactivity to overlapping peptides identified differences in the fine specificity between clones reactive against similar regions of MBP, further increasing the number of epitopes recognized. For example, the fine specificity of aminoterminus-reactive clones 31 N.2.18 and 31.N.2.54 could be distinguished by reactivity against aa 1-21 in the former clone only (Fig. 3). Similarly, encephalitogenicity in the blood-derived $T$ cell clones was not restricted by recognition of a single antigenic region of MBP. Four clones, each reactive against one of three different fragments of the molecule (aa 11-30,143-162, and 153-172), could efficiently transfer disease (Table II). In chimeric set $\mathbf{1}$, two different clones derived from the same animal, reactive respectively against the amino terminus and carboxyl terminus regions of MBP, were encephalitogenic. These data indicate diversity in the $T$ cell response to MBP that may result in clinical disease.

\section{Discussion}

MBP-reactive $T$ cells could readily be cloned from the peripheral blood of normal unimmunized $C$. jacchus primates. They were similar in several respects to the repertoire of circulating MBP-reactive cells described in human blood (8-12). First, circulating MBP-reactive $T$ cells occur at similar frequencies in the two species. Second, fine specificity mapping of different $\mathrm{T}$ cell clones derived from single individuals indicated diversity of recognition to multiple different epitopes of MBP. Thus, both in $C$. jacchus and human primate PBMC, a high frequency of MBP-reactive $T$ cells and diversity in MBP epitope recognition are characteristic.

The bone marrow chimerism in $C$. jacchus made possible the direct demonstration that MBP-reactive T cells were encephalitogenic following expansion and adoptive transfer. Thus, potential disease-inducing populations of MBP-reactive $T$ cells are normally present in primates. In rats, Schluesener and Wekerle were able to isolate a single encephalitogenic MBP-reactive $T$ cell line from lymph node of the EAE susceptible Lewis strain, but a similar line derived from the resistant BN strain was nonencephalitogenic (19). The Lewis line was successfully derived only after multiple negative attempts, and following negative selection of autologous MHC-reactive $\mathrm{T}$ cells. This was the first demonstration that EAE-inducing populations are present in the normal immune system. The current data demonstrate that these cells are in relative abundance in the circulation of normal outbred primates and are diverse in terms of their recognition of different epitopes of MBP. In $C$. jacchus, MBP- 


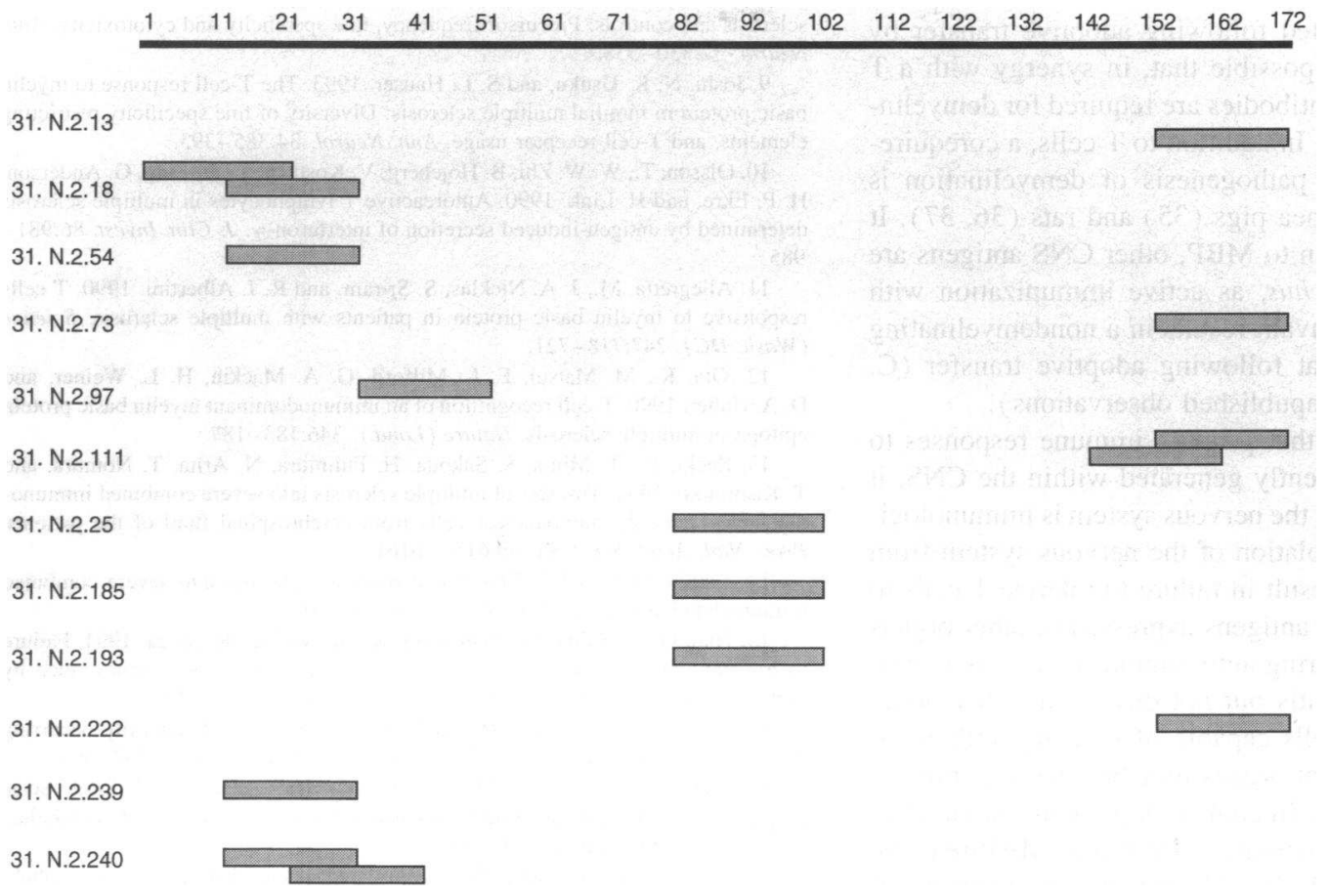

Figure 3. The natural repertoire of circulating MBP-reactive $\mathrm{T}$ cells in a healthy $C$. jacchus marmoset. Each clone was mapped for reactivity against synthetic 20-mer peptides corresponding to overlapping regions of human MBP. In this animal (chimeric set 3, animal A) at least seven discrete epitopes of MBP were recognized by different $\mathrm{T}$ cell clones.

reactive $\mathrm{T}$ cells are neither deleted, nor irreversibly tolerized, in the peripheral pool.

What mechanisms prevent development of spontaneous EAE in $C$. jacchus? MBP-reactive T cells must first penetrate the blood-brain barrier to mediate disease, a process that is influenced by activation (20). Activation by specific antigen, a relevant superantigen (21) or a mitogen (4), could enhance CNS migration of naturally occurring circulating encephalitogenic $T$ cells. The critical role of environmental exposure on the course of EAE was illustrated recently in a transgenic mouse model. A functional T cell receptor derived from an encephalitogenic MBP-reactive T cell was expressed in an MHC compatible host (22). All peripheral immune system CD4 cells expressed the transgenic $T$ cell receptor. Surprisingly, development of EAE in these animals required additional exposure to environmental pathogens or immunization with Bordetella pertussis. Transgenic animals unimmunized or housed in a germ-free environment did not spontaneously develop EAE. Thus, a large burden of encephalitogenic $T$ cells may be tolerated under some conditions without pathogenic consequences to the host. This appears also to be the case in $C$. jacchus. It is possible that active suppression might inhibit spontaneous induction of EAE by natural encephalitogenic $\mathrm{T}$ cell populations. In Lewis rats tolerized with CNS antigens (23) or recovered from EAE, suppressor $\mathrm{T}$ cell lines have been isolated that are capable of preventing EAE after adoptive transfer of encephalitogenic $\mathrm{T}$ cell lines (reviewed in 24 ). In $\mathrm{H}-2^{\prime}$ mice, recovery from MBP-induced EAE is associated with expansion of a CD4 $\mathrm{T}$ cell population that expresses the $\mathrm{V} \beta 14 \mathrm{~T}$ cell receptor gene segment and responds to a $\mathrm{V} \beta 8.2$ peptide expressed on most MBP-reactive encephalitogenic $T$ cells in this strain (25).

Mapping data in $C$. jacchus are in agreement with a previous report suggesting that the carboxy terminus of MBP contains antigenic determinants in primates (26) but also indicates that the natural encephalitogenic repertoire in $C$. jacchus is broad. In most inbred rodents examined, only exceedingly restricted populations of $T$ cells mediate acute EAE. For example, the encephalitogenic response to MBP is largely directed against the 1-9 amino terminus in the $\mathrm{H}-2^{u}$ mouse, against several epitopes within the 89-101 fragment in $\mathrm{H}-2^{\mathrm{s}}$ mouse, and against the 68-88 fragment in the Lewis rat (27-29). Similar to $C$. jacchus, diversity in recognition of MBP peptides appears to be characteristic of healthy humans and also patients with multiple sclerosis (MS) $(8,9,12,30-33)$. In outbred primates, both human and nonhuman, heterozygosity at different loci of the MHC may contribute to effective recognition of a greater number of epitopes of MBP than is possible in inbred rodents. Based upon analogy with C. jacchus, it is likely that, in humans, $\mathrm{T}$ cells that recognize diverse epitopes of MBP are potentially encephalitogenic. This concept has important implications for future attempts to specifically modulate an autoimmune response to MBP in humans.

Prominent and early demyelination is a hallmark of acute EAE induced in $C$. jacchus by active immunization with whole human white matter in adjuvant. ${ }^{2}$ Following adoptive transfer to naive recipients, MBP-reactive T cells induced clinical signs, inflammation in the CSF, and multifocal areas of disruption of the blood-brain barrier on MRI scans. In contrast, however, to the active immunization model, disease severity was mild and demyelination was conspicuously absent in adoptive transfer recipients. This indicates that, in $C$. jacchus, MBP-reactive T cells are capable of inducing CNS inflammation and clinical signs, but are not sufficient for plaque formation. In the active immunization model of EAE, early and intense macrophage infiltration occurs within lesions ${ }^{2}$ and these cells appear to mediate the characteristic demyelination that occurs. This macro- 
phage response was not noted following adoptive transfer by MBP-reactive $T$ cells. It is possible that, in synergy with a $T$ cell response to MBP, autoantibodies are required for demyelination to occur in $C$. jacchus. In addition to T cells, a corequirement for antibodies in the pathogenesis of demyelination is present in rabbits (34), guinea pigs $(35)$ and rats $(36,37)$. It is also likely that, in addition to MBP, other CNS antigens are relevant to EAE in $C$. jacchus, as active immunization with purified human MBP in adjuvant results in a nondemyelinating form of EAE similar to that following adoptive transfer (C. Genain and S. L. Hauser, unpublished observations ).

Based upon the finding that primary immune responses to some antigens are not efficiently generated within the CNS, it has long been postulated that the nervous system is immunologically privileged. Relative isolation of the nervous system from the immune system might result in failure to tolerize $T$ cells to CNS antigens, in contrast to antigens expressed in other organs of the body. Naturally occurring autoimmune $T$ cells may exist that mediate encephalomyelitis but not disease in other organ systems. Alternatively, $\mathrm{T}$ cells capable of inducing inflammatory disease in many different organs may be generally present in the circulation of primates. In contrast to humans and nonhuman primates, in which naturally occurring MBP-reactive PBMC are present $(8,9,12,30-33,38)$, we are unaware of any successful identification of MBP-reactive $T$ cells in the circulation of rodents. The $C$. jacchus marmoset is thus remarkable for circulating autoreactive $\mathrm{T}$ cells, close phylogeneic similarity to humans, and natural chimerism of bone marrow derived elements, all features unique to this model. These characteristics create an opportunity to study the regulation, traffic, and fate of disease-inducing $\mathrm{T}$ cells in normal primate homeostasis.

\section{Acknowledgments}

The authors wish to thank Shelley Ambrose, Laurie McCarthy, Katie Bunte, and Dayna Webber for technical assistance and Caroline Figoni for secretarial assistance.

These studies were supported by the National Institutes of Health grants RR-00168 and NS-30727, and by grants from the Penates Foundation and Devenshire Trust. Dr. Genain is a postdoctoral fellow of the National Multiple Sclerosis Society.

\section{References}

1. Paterson, P. Y. 1960. Transfer of allergic encephalomyelitis in rats by means of lymph node cells. J. Exp. Med. 111:119-135.

2. Pettinelli C. B., and D. E. McFarlin 1981. Adoptive transfer of experimental allergic encephalomyelitis in SJL/J mice after in vitro activation of lymph node cells by myelin basic protein: requirement for Lyt $1+2-\mathrm{T}$ lymphocytes. $J$. Immunol. 127:1420-1423.

3. Stone, S. H. 1961. Transfer of allergic encephalomyelitis by lymph node cells in inbred guinea pigs. Science (Wash. DC). 134:619-620.

4. Panitch, H. S. and D. E. McFarlin. 1977. Experimental allergic encephalomyelitis: enhancement of cell mediated transfer by concanavalin A. J. Immunol. 119:1134-1137.

5. Johnson, R. T., D. E. Griffin, R. L. Hirsh, J. S. Wolinsky, S. Roedenbeck, I. Lindo de Soriano, and A. Vaisberg. 1984. Measles encephalomyelitis. Clinical and immunologic studies. N. Engl. J. Med. 310:137-141.

6. Lisak, R. P., P. O. Behan, B. Zweiman, and T. Shetty. 1974. Cell-mediated immunity to myelin basic protein in acute disseminated encephalomyelitis. Neurology. 24:560-564.

7. Oksenberg, J. R., M. A. Panzara, A. B. Begovich, D. Mitchell, H. A. Erlich, R. S. Murray, R. Shimonkevitz, M. Sherrity, J. Rothbard, C. C. A. Bernard, and L. Steinman. 1993. Selection for T-cell receptor $\mathrm{V} \beta-\mathrm{D} \beta-\mathrm{J} \beta$ gene rearrangements with specificity for a myelin basic protein peptide in brain lesions of multiple sclerosis. Nature (Lond.). 362:68-70.

8. Jingwu, Z., R. Madaer, G. A. Hashim, Y. Chin, E. Van den Berg-Loonen, and J. C. M. Raus. 1992. Myelin basic protein-specific T lymphocytes in multiple sclerosis and controls: Precursor frequency, fine specificity and cytotoxicity. Ann. Neurol. 32:330-338.

9. Joshi, N. K. Usuku, and S. L. Hauser. 1993. The T-cell response to myelin basic protein in familial multiple sclerosis: Diversity of fine specificity restricting elements, and T-cell receptor usage. Ann. Neurol. 34:385-393.

10. Olsson, T., W. W. Zhi, B. Höjeberg, V. Kostulas, J. Yu-Ping, G. Anderson, H. P. Ekre, and H. Link. 1990. Autoreactive T lymphocytes in multiple sclerosis determined by antigen-induced secretion of interferon- $\gamma$. J. Clin. Invest. 86:981985.

11. Allegretta, M., J. A. Nicklas, S. Sriram, and R. J. Albertini. 1990. T cells responsive to myelin basic protein in patients with multiple sclerosis. Science (Wash. DC). 247:718-721.

12. Ota, K., M. Matsui, E. L. Milford, G. A. Mackin, H. L. Weiner, and D. A. Hafler. 1990. T-cell recognition of an immunodominant myelin basic protein epitope in multiple sclerosis. Nature (Lond.). 346:183-187.

13. Saeki, Y., T. Mima, S. Sakoda, H. Fujimura, N. Arita, T. Nomura, and T. Kishimoto. 1992. Transfer of multiple sclerosis into severe combined immunodeficiency mice by mononuclear cells from cerebrospinal fluid of the patients. Proc. Natl. Acad. Sci. USA. 89:6157-6161.

14. Lipton, H. L. 1993. Transfer of multiple sclerosis into severe combined immunodeficiency mice. Ann. Neurol. 34:115-116.

15. Hao, Q., T. Saida, M. Nishimura, K. Ozawa, and K. Saida. 1994. Failure to transfer multiple sclerosis into severe combined immunodeficiency mice by mononuclear cells from CSF of patients. Neurology. 44:163-165.

16. Picus, J., W. R. Aldrich, and N. L. Letvin. 1985. A naturally occurring bone marrow chimeric primate. Transplantation (Baltimore). 39:297-303.

17. Deibler, G. E., R. E. Martenson, and M. W. Kies. 1972. Large scale preparation of myelin basic protein in central nervous tissue of several mammalian species. Prep. Biochem. 2:139-165.

18. Tabira, J., and J. I. Kira. 1992. Strain and species differences of encephalitogenic determinants of myelin basic protein and proteolipid apoprotein. In $\mathrm{My}$ elin: Biology and Chemistry. R. E. Martenson, editor. CRC Press, Inc., Boca Raton, FL 783-799.

19. Schluesener, H. J., and H. Wekerle. 1985. Autoaggressive T lymphocyte lines recognizing the encephalitogenic region of myelin basic protein: in vitro selection from unprimed rat $\mathrm{T}$ lymphocyte populations. J. Immunol. 135:31283133 .

20. Hickey, W. F., B. L. Hsu, and H. Kimura. 1991. T-lymphocyte entry into the central nervous system. J. Neurosci. Res. 28:254-260.

21. Brocke, S., A. Gaur, C. Piercy, A. Gautam, K. Gijbels, C. G. Fathman, and L. Steinman. 1993. Induction of relapsing paralysis in experimental autoimmune encephalomyelitis by bacterial superantigen. Nature (Lond.). 365:642-644.

22. Goverman, J., A. Woods, L. Larson, L. P. Weiner, L. Hood, and D. M. Zaller. 1993. Transgenic mice that express a myelin basic protein-specific $\mathrm{T}$ cell receptor develop spontaneous autoimmunity. Cell. 72:551-560.

23. Miller, A., Z. J. Zhang, R. A. Sobel, A. Al-Sabbagh, and H. L. Weiner. 1993. Suppression of experimental autoimmune encephalomyelitis by oral administration of myelin basic protein. VI. Suppression of adoptively transfered disease and differential effects of oral vs. intravenous tolerization. J. Neuroimmunol. 46:73-82.

24. Arnon, R., and D. Teitelbaum. 1993. On the existence of suppressor cells. Int. Arch. Allergy Immunol. 100:2-7.

25. Kumar, V., and E. E. Sercarz. 1993. The involvement of T cell receptor peptide-specific regulatory $\mathrm{CD} 4{ }^{+} \mathrm{T}$ cells in recovery from antigen-induced autoimmune disease. J. Exp. Med. 178:909-916.

26. Karkhanis, Y. D., D. J. Carlo, S. W. Brostoff, and E. H. Eylar. 1975 Allergic Encephalomyelitis: isolation of an encephalitogenic peptide active in the monkey. J. Biol. Chem. 250:1718-1722.

27. Zamvil, S. S., D. J. Mitchell, A. C. Moore, K. Kitamura, L. Steinman, and J. B. Rothbard. 1986. T-cell epitope of the autoantigen myelin basic protein that induces encephalomyelitis. Nature (Lond.). 324:258-260.

28. Sakai, K., S. S. Zamvil, D. J. Mitchell, M. Lim, J. B. Rothbard, and L. Steinman. 1988. Characterization of a major encephalitogenic T-cell epitope in $\mathrm{SJL} / \mathrm{J}$ mice with synthetic oligopeptides of myelin basic protein. J. Neuroimmunol. 19:821-832.

29. Kibler, R. F., R. B. Fritz, F. C.-H. J. Chou, C.-H. J. Chou, N. Y. Peacock, N. M. Brown, and D. E. McFarlin. 1977. Immune response of Lewis rats to peptide $\mathrm{C} 1$ (residues $68-88$ ) of guinea pig and rat myelin basic proteins. J. Exp. Med. 146:1323-1331.

30. Martin, R., D. Jaraquemada, M. Flerlage, J. R. Richert, J. Whitaker, E. O. Long, D. E. McFarlin, and H. F. McFarland. 1990. Fine specificity and HLA restriction of myelin basic protein-specific cytotoxic $T$ cell lines from multiple sclerosis patients and healthy individuals. J. Immunol. 145:540-548.

31. Pette, M., K. Fujita, D. Wilkinson, D. M. Altmann, J. Trowsdale, G. Giegerich, A. Hinkkanen, J. T. Epplen, L. Kappos, and H. Wekerle. 1990. Myelin autoreactivity in multiple sclerosis: recognition of myelin basic protein in the context of HLA-DR2 products by $\mathrm{T}$ lymphocytes of multiple sclerosis patients and healthy donors. Proc. Natl. Acad. Sci. USA. 87:7968-7972.

32. Chou, Y. K., M. Vainiene, R. Whitham, D. Bourdette, C. H-J. Chou, G. Hashim, H. Offner, and A. A. Vandenbark. 1989. Response of human T lympho- 
cyte lines to myelin basic protein: Association of dominant epitopes with HLA class II restriction molecules. J. Neurosci. Res. 23:207-216.

33. Liblau, R., E. Tournier-Lasserve, J. Maciazek, G. Dumas, O. D. Siffert, G. Hashim, and M. A. Bach. 1991. T cell response to myelin basic protein epitopes in multiple sclerosis patients and healthy subjects. Eur. J. Immunol. 21:13911395.

34. Brosnan, C. F., G. L. Stoner, B. R. Bloom, and H. M. Wisniewski. 1977. Studies on demyelination by activated lymphocytes in the rabbit eye. II. Antibodydependent cell-mediated demyelination. J. Immunol. 118:2103-2110.

35. Grudke-Igbal, I., C. S. Raine, A. B. Johnson, C. F. Brosnan, and M. B. Bornstein. 1981. Experimental allergic encephalomyelitis: characterization of serum factors causing demyelination and swelling of myelin. J. Neurol. Sci. 50:63-79.

36. Lassmann, H. C. Brunner, M. Bradl, and C. Linington. 1988. Experimenta allergic encephalomyelitis: the balance between encephalitogenic $\mathrm{T}$ lymphocytes and demyelinating antibodies determines size and structure of demyelinated lesions. Acta Neuropathol. 75:566-576.

37. Willenberg, D. O., and S. J. Prowse. 1983. Immunoglobulin-deficient rats fail to develop experimental allergic encephalomyelitis. J. Neuroimmunol. 5:99-109.

38. Massacesi, L., N. Joshi, D. Lee-Parritz, A. Rombos, N. L. Letvin, and S. L. Hauser. 1992. Experimental allergic encephalomyelitis in cynomolgus monkeys. Quantitation of T cell responses in peripheral blood. J. Clin. Invest. 90:399-404. 